\title{
The Effect Of Infographic On English Language Education Students' Speaking Competence
}

\author{
Cahyani, N.M.A.M ${ }^{1}$, Sintya Desi, K. ${ }^{2}$, Myartawan, I.P.N.W. ${ }^{3}$
}

${ }^{123}$ English Language Education, Ganesha University of Education, Bali, Indonesia

\author{
A R T I C L E I N F O \\ Article history: \\ Received 3 July 2020 \\ Received in revised \\ Form 01 August 2020 \\ Accepted 18 August \\ 2020 \\ Available online 3 \\ October 2020 \\ Keywords: \\ infographic, speaking \\ competence, \\ instructional media
}

\begin{abstract}
A B S T R A C T
This research aimed at investigating the effect of infographic towards university students' speaking competence. The research design was a quasiexperiment with a post-test-only control group design. The research population included the $2^{\text {nd }}$ semester students of English Language Education of UNDIKSHA Indonesia in academic year 2019/2020. Through lottery, the samples were divided into experimental group which was taught by using infographic and control group which was taught by using conventional strategy. The data were collected through post-test in a form of speaking performance. The data were analyzed using descriptive and inferential statistics analysis. The result of data analysis showed that the students in experimental group performed better than the students in control group. It was also supported by the descriptive statistics result which showed the mean score of experimental group $(\bar{X}=82.89)$ was higher than the control group $(\bar{X}=75.03)$. The result of the T-test showed that the value of the tobs was 5.422 meanwhile the value of $t_{c v}$ was 1.674 which means tobs was higher than tcv. Moreover, the significant value of the data
\end{abstract} was 0.001 or less than 0.05 . The result of effect size was 1.45 that belongs to the large effect category. Based on the findings, it was concluded that there was a significant effect of using infographic as a media on students' speaking competence.

\section{Introduction}

As one of $21^{\text {st }}$ century skills, communication is really important for nowadays era, especially for second language learner students. As an effective communicator, students are expected to practice or speak more in English. It is also supported by Trilling \& Fadel (2009), who mentioned that the students should be able to communicate their thoughts or ideas by using verbal or nonverbal communication, listen to knowledge, values, attitudes and intentions in order to decipher its meaning, communicate based on purposes. Unfortunately, practicing speaking skill is still difficult for most of EFL students in daily conversation. Most Asian students are not able to speak English due to English is not their first language, although the curriculum provided English course for speaking practice. There are several issues by the students when it comes to speak, such as prohibition, have nothing to say, low participation and the use of mother tongue (Ur, 2009). Based on obstacles mentioned above, the EFL students are still struggling in expressing their idea through speaking and this is one of problems that can be found in learning English where EFL students think that speaking is really hard.

Yanar \& Tutunis (2016) stated that the role of the language and media are needed to be focused on and analyzed in a good perspective in terms learning. Yanar \& Tutunis (2016) stated that the role of the language and media are needed to be focused on and analyzed in a good perspective in terms learning. In this information era, the students should acquire visual literacy to comprehend the visual material presented in English Matrix \& Hodson, 2014). Petersson (1994) defined visual literacy as someone's ability in understanding information or figure for a more effective communication. Visual literacy means the ability of interpreting information from an image. Visual literacy can be used to summarize a whole information into a short and interesting way. Therefore, introducing visual learning aids to the students might be an effective option as learning media.

As one of the example of visual literacy media, infographic has been used in education. According to Ferreira (2014), an infographic or information graphic is a type of picture that elaborates data with 
design which can help individuals and organizations concisely communicate messages to their audience. Mohd Noh et al. (2014) stated that the higher learning institutions should implement infographic in the learning process. Infographic is a part of visual literacy media that can be an alternative for students to encourage their literacy interest. Mubarok \& Asri (2020)conducted an experiment about testing out how the infographic affect students' skill in summary writing. The result showed that the students taught using infographic have higher score rather than students taught without infographic. Based on the college students, Bicen \& Beheshti (2017) mentioned that their research showed the students gave positive responses through the implementation of infographic in the learning process. Based on these previous research, it can be concluded that the infographic is really helpful to be used as a media for the students.

Based on the previous studies mentioned above, the researcher intended to investigate the effect of infographic on English Language Education (ELE) students' speaking competence. The researcher was interested to conduct an experiment about infographic as a media that is rarely used in speaking course especially in English Language Education.

\section{Methods}

This study used a quasi-experimental research with a post-test only control group design. This research aimed at find the significance difference on students' speaking competence of students that will be taught by using infographic and students who will be taught without implementing infographic. According to Gay et al. (2012) post-test only control group design is similar with pre-test and post-test, yet there only a post-test in post-test only control group design. There will be two groups in this research; experimental group and control group. Experimental group will receive the treatment and control group will not. The treatment of this experiment will be given for 6 times. At the end of period time, both group will be given same post test. The illustration of the research design is presented below.

Table 1. Research Design

\begin{tabular}{|c|c|c|}
\hline Types of Group & Treatment & Post-test \\
\hline Experimental Group (EG) & $\mathrm{X}$ & 0 \\
\hline Control Group (CG) & $\mathrm{Y}$ & 0 \\
\hline
\end{tabular}

According to Creswell (2012) a population is defined as a group of individuals who have the same characteristics. The population of this study are the second semester students in English Language Education of Ganesha University of Education. The sample were from 2 classes of second semester which consist of 28 students each class. In order to analyze the homogeneity and normality of sample, the researcher used SPPS 24.0 to make sure both groups were homogenous and distributed normally. The instrument used in this research were post-test (speaking test) and scoring rubric (adapted from Burns (1998)). Also, the researcher conducted content and reliability validity on the speaking rubric to make sure the rubric was valid and reliable. The data were analyzed through descriptive and inferential statistics analysis, and effect size calculation.

\section{Result and Discussion}

The post-test results of this research were analyzed quantitatively by using descriptive and inferential statistic, and effect size calculation to know whether or not infographic gives significant effect towards the second semester students' speaking competence in English Language Education, Ganesha University of Education.

Table 2. The Result of Descriptive Statistical Analysis

\begin{tabular}{ccccccccc}
\hline Group & Mean & $\begin{array}{l}\text { Standard } \\
\text { Deviation }\end{array}$ & Median & Mode & $\begin{array}{l}\text { Max } \\
\text { Score }\end{array}$ & $\begin{array}{l}\text { Min } \\
\text { Score }\end{array}$ & Range & Variance \\
\hline Experimental & 82.89 & 5.78 & 83 & 80 & 93 & 70 & 23 & 33.5 \\
\hline Control & 75.03 & 5.02 & 75 & 75 & 87 & 65 & 22 & 25.29 \\
\hline
\end{tabular}


From the data above, the score of the students' speaking competence in experimental group and the control group show significant difference, in which the experimental group score was (mean $=82.89$, variance $=33.5$, std deviation $=5.78$ ) and the score of the control group was (mean $=75.03$, variance $=$ 25.29 , std. deviation $=5.02$ ). It can be concluded that the experimental group which was the group taught using infographic achieved higher score than the control group which was taught using conventional method or without using infographic.

Normality and homogeneity tests were conducted after the treatment based on the students' post-test score in order to make sure both groups were homogenous and distributed normally and the result showed these groups were homogenous and distributed normally. The result of normality and homogeneity were presented in the table below.

Table 3. Normality Test Result Kolmogorov-Smirnov ${ }^{b}$

\begin{tabular}{llllll}
\hline & \multicolumn{3}{c}{ Statisti } & Sig. \\
Group & $\mathbf{c}$ & $\mathbf{d f}$ &, 133 \\
\hline & Control &, 146 & 28 & \\
\cline { 2 - 5 } & Experimenta & 133 & 28 &, $200^{*}$ \\
\hline
\end{tabular}

Table 4. Homogeneity Test Result Test of Homogenei1

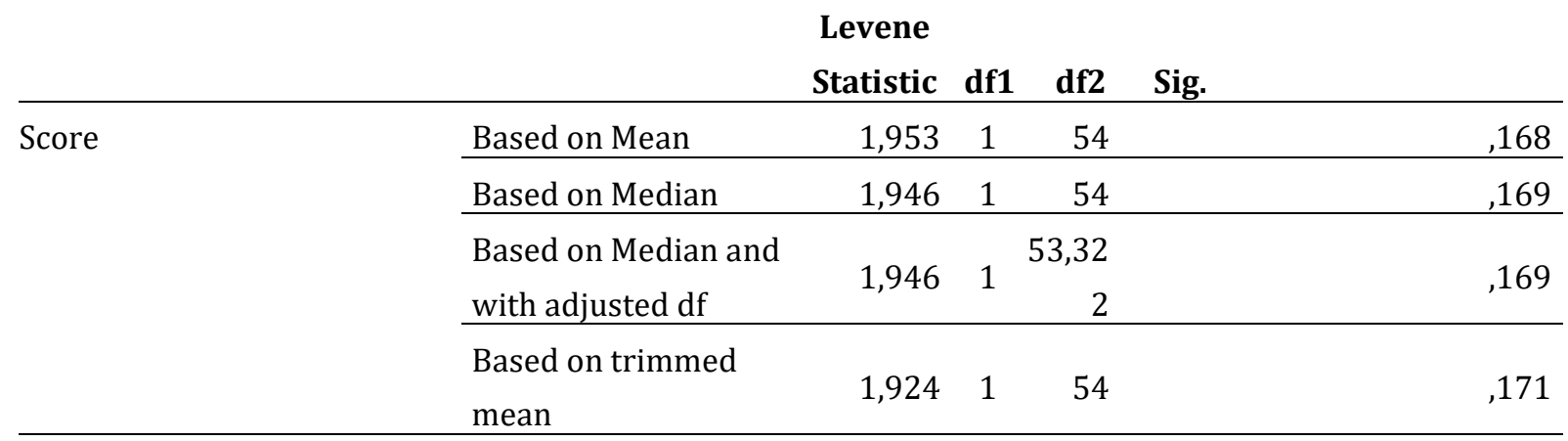

After conducting the normality and homogeneity test, an independent t-test was used to measure the significant difference on students' speaking competence between students taught using infograpic and students taught without using infograpic in English Language Education Department. The t-test was conducted using SPSS program.

Table 5. The Result of Independent t-test Independent Samples Test

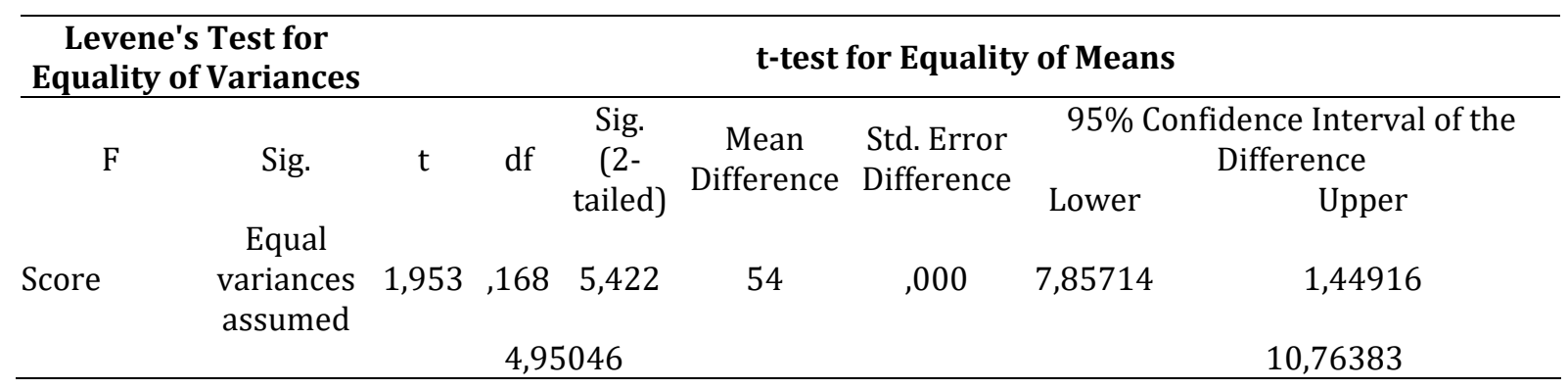


The result shows that $t$ observed was 5.422 which was higher than $t$ critical value which is $1.674(d f=54$, $\alpha=0.05)$. Furthermore, the significant two-tailed also reveals that the significant two-tailed value was lower than 0.05 in the equal variances assumed. Based on those results, null hypothesis $\left(\mathrm{H}_{0}\right)$ was rejected and the alternative hypothesis $\left(\mathrm{H}_{\mathrm{a}}\right)$ was accepted. This revealed that there is a significant difference on students' speaking competence between students taught using infographic and students taught without using infographic in English Language Education Department. The other result was the effect size calculation which was conducted in order to check the influence of ind ependent variable to the dependent variable to know how the treatment works. The calculation was done by using effect size calculator. The category of effect size presented in the table below.

Table 6. Effect Size Category

\begin{tabular}{cc}
\hline Effect Size (d) & Level \\
\hline $0.20 \leq \mathrm{d} \leq 0.50$ & Small \\
$0.50 \leq \mathrm{d} \leq 0.80$ & Medium \\
$\mathrm{d} \geq 0.80$ & Large \\
\hline
\end{tabular}

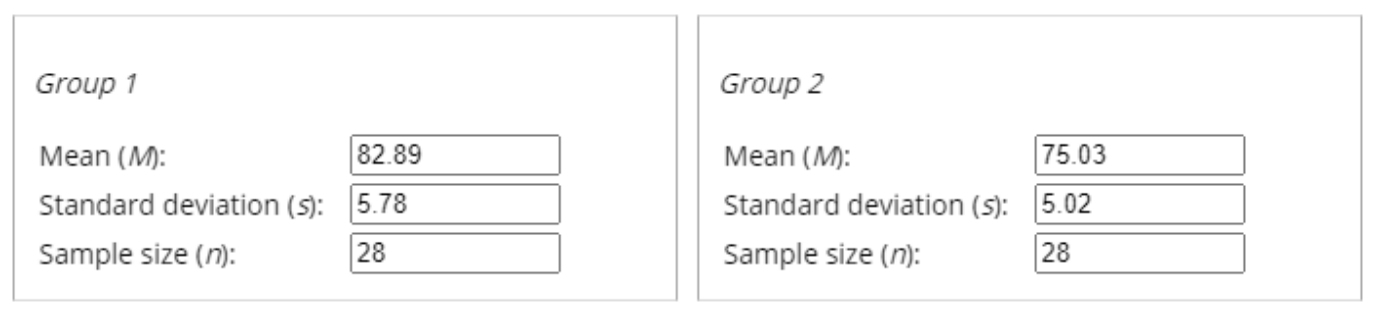

Cohen's $d=(75.03-82.89) / 5.413354=1.451965$.

Figure 1. Effect Size Calculation Result

Based on the result from Cohen's d calculation, it shows that the effect size was 1.45. This revealed that there was a large effect on the use of infographic on students' speaking competence in English Language Education Department since the scale from Cohen's shows $\mathrm{d} \geq 0.80$ is categorized as having a large effect size.

According to the result of descriptive and inferential statistics analysis, hypothesis testing, and effect size calculation, the results showed that the students in experimental group performed better than the students in control group. As the researcher conducted the experiment, the researcher also observed students' behavior and response while doing the treatment. Based on the researcher's observation, the students were really excited when the researcher explained about the infographic and its elements. After the explanation, the next session was practicing on designing an infographic by the students with a topic of introducing a favorite person or idol. On the first time they spoke with using infographic, some of the students were not used yet with using infographic so they tried to memorize then continuing their presentation instead of looking at the infographic. Most of the students were really helped by the use of infographic especially for students who could not remember their speech or material. Once the experimental students forgot about what to say, they had the infographic with them. So, this observation result supported the descriptive and inferential analysis result.

Finally, it can be inferred that infographic proven effective for improving students' speaking competence. It was also supported by the alternative hypothesis which was accepted and there was significant effect towards students' speaking competence of the 2nd semester in English Language Education UNDIKSHA in academic year 2019/2020.

\section{Conclusion}

Based on the result of the findings and discussion of the data analysis from, it showed that infographic gave significant effect towards students' speaking competence on the $2^{\text {nd }}$ semester of English 
Language Education UNDIKSHA in academic year 2019/2020. It was proven by the result of the descriptive and inferential statistics analysis. Based on the result of descriptive analysis, the mean score of experimental group which was taught by using infographic was 82.89, meanwhile the mean score of the control group which was taught without using infographic was 75.03. It can be concluded that the experimental group could achieve better achievement rather than the control group based on the mean score of both groups. It also proven that there is significant effect on the students' speaking competence who were taught by using infographic.

Furthermore, from the inferential analysis which includes the hypothesis testing (independent $\mathrm{t}$ test) showed that the t-observed of the data was higher than the $t$ critical value. The comparison between t-observed and $t$ critical value was $5.422>1.674$ which means that the value of t-observed was higher than the value of $t$ critical value. Besides, the significance value of the data was $0.000<0.05$. Thus, these findings proved that there was a significant effect of infographic on English Language Education students' speaking competence.

\section{References}

Bicen, Huseyin \& Beheshti, M. (2017). The Psychological Impact of Infographics in Education. BRAIN Broad Research in Artificial Intelligence and Neuroscience, 8(4).

Creswell, J., W., (2012), Research design Pendekatan kualitatif, Kuantitatif dan Mixed; Cetakan ke-2, Yogyakarta: Pustaka Pelajar.

Gay, L.R., Mills, G.E. and Airasian, P.W. (2012) Educational Research Competencies for Analysis and Application. 10th Edition, Pearson, Upper Saddle River.

Matrix, S., \& Hodson, J. (2014). Teaching with Infographics: Practicing new digital competencies and visual literacies. Journal of Pedagogic Development, 4(2), 17-27.

Mohd Noh, Mohd Amin \& Shamsudin, Wan Nur \& Amin Nudin, Anith \& Narimah, Nik \& Harun, Mohd. (2014). The Use of Infographics as a Tool for Facilitating Learning. 559-567. 10.1007/978-981-287332-3_57.

Mubarok, Faiz \& Asri, Atiqah. (2020). Infographics: Media for Improving Students' Writing Abilities. KnE Social Sciences. 10.18502/kss.v4i4.6469. Shen, Ming-yueh \& Chiu, Tzu-yen. (2019). EFL Learners' English Speaking Difficulties and Strategy Use. Education and Linguistics Research. 5. 88. 10.5296/elr.v5i2.15333.

Trilling \& Fadel. (2009). 21st Century Learning Skills. San Francisco, CA: John Wiley \& Sons.

Ur, P. (2009). A course in Language Teaching: Practice of theory. (M. Williams \& T. Wright, Eds.) (17th ed.). New York: Cambridge University Press. Retrieved http://www.banarvan.com/DynamicContent/UsersDirectory/admin/MyFiles/Teaching Syllabus/penny ur old version.pdf

Yanar, M. \& Tütüniş, B. (2016). The impact of mass media tools on EFL students'speaking skills case. International Online Journal of Education and Teaching (IOJET), 3(1). 2-24. 